\title{
KINERJA KEUANGAN DAN HARGA SAHAM
}

\author{
Siti Atikah \\ Sapto Hendri BS \\ Intan Rakhmawati \\ Wirawan Suhaedi \\ Baiq Rosyida DA.
}

\begin{abstract}
Abstrak
Salah satu faktor yang menjadi bahan pertimbangan seorang investor atau calon investor saham dalam menentukan harga tawaran beli maupun tawaran jual adalah kinerja keuangan. Berbagai literatur menyatakan bahwa mahal atau murahnya harga saham ditunjukkan oleh kinerja keuangan. Penelitian ini bertujuan untuk menguji secara empiris arah atau hubungan kinerja keuangan dengan harga saham pada perusahaan sektor pertanian dan sektor pertambangan pada periode 2013 hingga 2015. Penelitian ini juga mengelompokkan kinerja keuangan berdasarkan harga saham yang kurang dari Rp 500 dan harga saham diatas Rp 500.

Hasil analisis menunjukkan bahwa current ratio, debt to equity ratio, net profit margin, return on equity, earning per share, dan price earning ratio perusahaan sektor pertanian memiliki arah yang negatif terhadap harga saham, sedangkan arah positif ditunjukkan oleh asset turnover ratio, debt to total asset, financial leverage dan gross profit margin. Hasil yang berbeda terjadi pada harga saham perusahaan di sektor pertambangan. asset turnover ratio, debt to total asset, financial leverage, gross profit margin dan price earning ratio perusahaan sektor pertambangan memiliki arah yang negatif terhadap harga saham.
\end{abstract}

Kata Kunci: Harga Saham, Kinerja Keuangan, dan Faktor Fundamental

\section{PENDAHULUAN}

\section{Latarbelakang}

Investor melakukan perdagangan saham di pasar modal untuk meningkatkan kesejahteraan mereka. Untuk itu, investor harus mempertimbangkan saham mana yang harus di beli, berapa harganya serta memprediksi risiko yang sanggup ditanggung. Faktor-faktor yang mempengaruhi pertimbangan investor antara lain kebijakan moneter, kebijakan industri, kebijakan keuangan, nilai tukar, informasi akuntansi, dan tentunya, harapan investor. 
Informasi akuntansi merupakan informasi yang paling banyak digunakan oleh investor maupun calon investor dalam memprediksi harga saham. Informasi akuntansi adalah informasi yang disediakan dalam pelaporan keuangan. Informasi ini digunakan untuk memprediksi kinerja emiten saham maupun menentukan mahal atau murahnya harga saham emiten. Menurut Wang et.al (2013), informasi akuntansi dapat berkorelasi positif dengan harga saham, namun dengan tingkat signifikansi yang berbeda antara satu informasi dengan informasi lainnya.

Hasil analisis dari informasi keuangan, dapat memberikan kekecewaan bagi penggunanya, ketika hasil analisis berbeda dengan kenyataannya. Dalam jangka pendek, analisis fundamental memiliki pengaruh minor terhadap harga saham. Sentimen dan emosi pasar memiliki pengaruh yang jauh lebih besar daripada analisis fundamental (Liembono and Mulyana 2016). Analisis fundamental akan lebih bermanfaat digunakan dalam investasi saham dengan jangka waktu menengah hingga jangka panjang.

Informasi akuntansi yang manakah yang mempengaruhi harga saham? Menurut Wang et.al (2013), Earning Per Share (EPS) dan Return On Equity (ROE) memiliki pengaruh yang sangat signifikan. Dimitropoulos dan Asteriou (2009) turut menyatakan kesepakatannya, bahwa profitabilitas-lah yang mempengaruhi harga saham secara signifikan. Hasil pengujian Gallizo dan Salvador (2016) menunjukkan bahwa ukuran perusahaan dan rasio perputaran aset (asset turnover ratio atau ATR) yang sangat mempengaruhi harga saham.

Salah satu tujuan investasi adalah meningkatkan kesejahteraan. Tingkat kesejahteraan ini ditinjau dari tingkat imbal hasil yang diperoleh. Investor saham akan mempertimbangkan kemungkinan meningkatkan imbal hasil mereka dari informasi laba yang diperoleh emiten saham. Informasi Return on Asset (ROA) dan ROE mempengaruhi tingkat imbal hasil saham investor, sementara Debt to Equity Ratio (DER), Current Ratio (CR) dan Total Asset Turn Over (TATO) tidak berpengaruh (Ismail and Witarno 2014). Penelitian ini akan menguji keterkaitan antara informasi kinerja keuangan dengan tingkat harga pasar saham emiten, dengan mengelompokkan harga pasar saham menjadi kelompok harga saham yang tinggi dan rendah.

\section{Masalah Penelitian}

Adapun perumusan masalah dalam penelitian ini:

1. Bagaimanakah kinerja keuangan dan harga saham perusahaan di sektor pertambangan?

2. Bagaimanakah kinerja keuangan dan harga saham perusahaan di sektor pertanian? 
3. Bagaimanakah hubungan antara kinerja keuangan perusahaan di sektor pertambangan dengan harga pasar saham mereka?

4. Bagaimanakah hubungan antara kinerja keuangan perusahaan di sektor pertanian dengan harga pasar saham mereka?

\section{Tujuan dan Manfaat Penelitian}

Penelitian ini untuk menguji secara empiris keterkaitan kinerja keuangan dengan harga saham. Hasil penelitian ini diharapkan dapat bermanfaat bagi:

- Investor atau calon investor dalam mengambil keputusan membeli atau menjual saham, dengan menggunakan analisis fundamental.

- Peneliti lain untuk menggunakan penelitian ini sebagai dasar penelitian berikutnya.

- Akademisi dapat menggunakan penelitian ini sebagai bahan pengembangan bahan ajar matakuliah yang terkait.

\section{TINJAUAN PUSTAKA}

\section{Teori Sinyal dan Harga Saham}

Informasi akuntansi yang diumumkan oleh emiten saham, menjadi salah satu sinyal bagi investor untuk mengambil suatu keputusan. Keputusan yang dilakukan antara lain keputusan membeli atau menjual saham. Ketika investor memutuskan membeli atau menjual, pertanyaan yang timbul adalah, mahal ataukah murah, bagus atau tidak bagus. Ada yang berpendapat bahwa harga saham yang murah harus dibeli karena murah, padahal, bisa jadi, harganya murah karena saham emiten tersebut tidak bagus atau memiliki kinerja yang tidak bagus. (Liembono and Mulyana 2016).

Saham yang bagus dan sekaligus murah sangat jarang dijumpai. Indikator saham yang bagus dan murah dapat dijelaskan dalam tabel berikut (Liembono and Mulyana 2016):

Tabel 1. Indikator Saham Murah dan Bagus

\begin{tabular}{|c|c|}
\hline MURAH & BAGUS \\
\hline $\begin{array}{l}\begin{array}{l}\text { Price Earning Ratio (PER) } \\
\text { kecil }\end{array} \\
\end{array}$ & ROE tinggi \\
\hline $\begin{array}{l}\text { Price to Book Value (PBV) } \\
\text { kecil }\end{array}$ & Margin tinggi \\
\hline & Pertumbuhan bagus \\
\hline
\end{tabular}

Murah atau mahalnya suatu saham tidak terkait dengan harga saham tersebut. Murah atau mahalnya suatu saham ditentukan oleh rasio harga saham tersebut dengan aset maupun laba saham tersebut. Sementara bagus 
Siti Atikah, Sapto Hendri BS., Intan R., Wirawan S., Bq. Rosyida DA: Kinerja Keuangan ...

atau tidaknya suatu saham ditentukan oleh berbagai faktor fundamental seperti disebutkan dalam tabel 1 . Informasi PER, PBV, ROE, dan informasi keuangan lainnya, disajikan oleh manajemen dalam pelaporan keuangannya.

\section{Kinerja Keuangan}

Kinerja pada umumnya diukur melalui perspektif keuangan dan perspektif non keuangan. Kinerja perusahaan dari perspektif keuangan dapat diukur dari komponen-komponen yang disajikan dalam laporan keuangan. Analisis keuangan akan terbagi dalam tiga bagian besar, yaitu analisis profitabilitas, analisis risiko dan analisis sumber dan penggunaan dana (Subramanyam and Wild 2010). Analisis profitabilitas dilakukan untuk mengevaluasi tingkat pengembalian investasi perusahaan, seperti ROA dan ROE. Analisis risiko digunakan untuk mengevaluasi kemampuan perusahaan untuk memenuhi komitmennya. Rasio keuangan yang digunakan dalam analisis risiko antara lain solvabilitas dan likuiditas. Terakhir, analisis sumber dan penggunaan dana, bertujuan memberikan pandangan tentang implikasi pendanaan perusahaan di masa yang akan datang.

Analisis atas informasi keuangan yang disajikan dalam laporan keuangan, menjadi bagian yang tak terpisahkan dalam analisis bisnis. Analisis bisnis berguna dalam melakukan keputusan bisnis, seperti memilih investasi dalam surat berharga utang atau ekuitas, seperti yang disajikan dalam tabel 1. Dalam tabel 1 disebutkan bahwa ROE dan margin yang tinggi menunjukkan kinerja saham emiten yang bagus. Salehnejad dan brave (2010), Wang et.al (2013), Dimitropoulos dan Asteriou (2009) serta Ismail dan Witarno (2014) menyatakan bahwa informasi ROE dan ROA berpengaruh signifikan terhadap harga saham.

Informasi keuangan lain diprediksi dapat memberikan sinyal kepada investor untuk membeli atau menjual saham, untuk mengurangi atau menekan risiko investasi mereka. Gallizo dan Salvador (2016) menyebutkan jika ukuran perusahaan dan rasio perputaran aset dapat mempengaruhi fluktuasi harga saham, namun Ismail dan Witarno (2014) memberikan bukti yang berbeda terkait dengan rasio perputaran aset. Informasi lain, seperti DER dan CR, juga diakui Ismail dan Witarno (2014) tidak berpengaruh terhadap fluktuasi harga saham. Gambaran umum dari hubungan informasi keuangan dengan harga saham sebagai berikut:

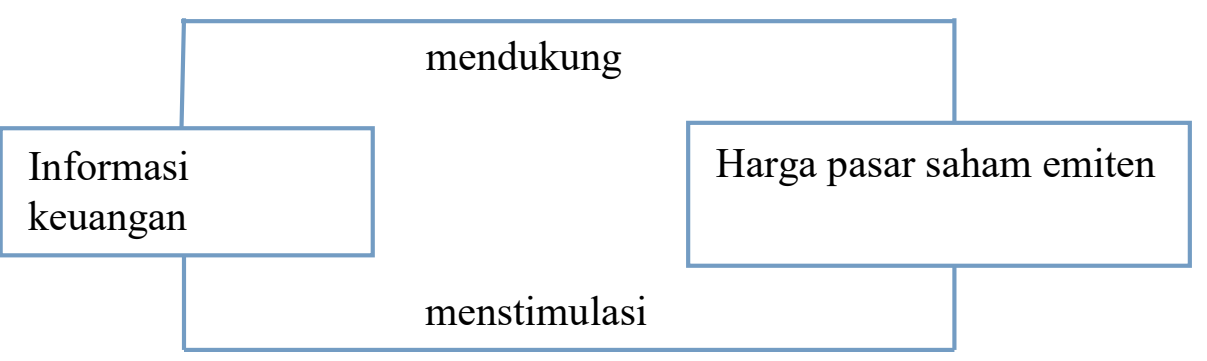


Dengan demikian, hipotesis penelitian yang diajukan adalah:

$\mathrm{H} 1$ : Rasio perputaran aset, DER, current ratio, ROA, ROE, Debt to total asset, gross profit margin, net operating margin, dan financial leverage pada tahun berjalan, masing-masing berkorelasi positif terhadap harga saham tahun berikutnya

\section{METODE PENELITIAN}

\section{Jenis Penelitian}

Penelitian ini merupakan penelitian deskriptif. Penelitian ini berupaya untuk mendeskripsikan korelasi antara kinerja keuangan dan harga saham.

\section{Populasi dan Sampel}

Penelitian ini akan menggunakan pelaporan keuangan perusahaan sektor pertambangan dan sektor pertanian yang terdaftar di Bursa Efek Indonesia (BEI) dan telah disediakan dalam situs idx.co.id. Kedua sektor ini terpilih dipandang dari sudut bahwa keduanya merupakan sektor utama yang terdapat di BEI. Periode waktu pengamatan yang dipilih adalah laporan keuangan yang berakhir pada tahun 2015 .

\section{Identifikasi dan Definisi Operasional Variabel}

Variabel independen yang digunakan dalam penelitian ini adalah kinerja keuangan. Kinerja keuangan menggambarkan kemampuan perusahaan untuk mendistribusikan kekayaan dan laba untuk kesejahteraan stakeholder. Kinerja keuangan ini terdiri dari

$$
\begin{aligned}
& \text { Current Ratio }=\frac{\text { Aset Lancar }}{\text { Kewajiban Lancar }} \\
& \text { Asset Turnover }=\frac{\text { Penjualan bersih }}{\text { Total Aset }} \\
& \text { Debt to total asset }=\frac{\text { total } \text { kewajiban }}{\text { total aset }} \\
& \text { Debt to Equity Ratio }=\frac{\text { Total Kewajiban }}{\text { Total Ekuitas }} \\
& \text { Financial Leverage }=\frac{\text { Total Aset }}{\text { Total Ekuitas }} \\
& \text { Gross Margin }=\frac{\text { Laba kotor }}{\text { Penjualan bersih }} \\
& \text { Operating Margin }=\frac{\text { Laba Operasi }}{\text { Penjualan bersih }} \\
& \text { Return on Equity }=\frac{\text { Laba bersih }}{\text { ekuitas }}
\end{aligned}
$$


Siti Atikah, Sapto Hendri BS., Intan R., Wirawan S., Bq. Rosyida DA: Kinerja Keuangan ...

Return on Asset $=\frac{\text { Laba setelah pajak }}{\text { Total Aset }}$

Earning Per Share $=\frac{\text { Laba bersih setelah pajak }}{\text { jumlah saham beredar }}$

Variabel kedua, yaitu variabel dependen yang digunakan dalam penelitian ini adalah harga saham. Harga saham yang digunakan adalah harga pasar saham pada tanggal penutupan perdagangan tahun 2013 hingga 2015.

\section{Metode Analisis}

Analisis dalam penelitian ini akan dilakukan dengan:

a. Tabulasi, untuk menjelaskan gambaran umum kondisi kinerja keuangan masing-masing sektor (pertambangan dan pertanian), yang dibedakan menjadi dua bagian. Bagian pertama, kelompok perusahaan yang memiliki harga pasar saham per 31 Desember 2015 diatas Rp 500 dan bagian kedua adalah kelompok perusahaan yang memiliki harga pasar saham per 31 Desember 2015 kurang dari Rp 500.

b. Analisis regresi. Analisis ini digunakan untuk menguji hubungan antara variabel kinerja keuangan dengan harga pasar saham akhir tahun dalam periode 2013 hingga 2015. Analisis ini dilakukan untuk masingmasing sektor yang diuji.

\section{HASIL DAN PEMBAHASAN}

\section{Kinerja Keuangan Perusahaan Sektor Pertanian}

Sektor pertanian, merupakan salah satu dari sektor utama yang terdapat di Bursa Efek Indonesia (BEI). Perusahaan yang bergerak di sektor pertanian, meliputi subsektor tanaman pangan, perkebunan, perternakan, perikanan, kehutanan dan subsektor lainnya. Jumlah keseluruhan perusahaan pada sektor ini adalah 21 perusahaan dan hanya 6 perusahaan yang sahamnya masuk dalam kategori "papan pengembangan".

Harga saham tertinggi di sektor pertanian dari tahun 2013 hingga 2015 dipimpin oleh Astra Agro Lestari Tbk (AALI). Harga saham AALI berada pada kisaran Rp 15.000 hingga Rp 25.000. Harga saham terendah di sektor ini sebesar Rp 50,- selama 2-3 tahun berturut-turut dicapai oleh saham MAGP dan UNSP. Profil harga saham di sektor pertanian ini terlihat dalam gambar berikut:

Gambar 2. Harga Saham Sektor Pertanian Periode 2013-2015 


\begin{tabular}{|c|c|c|c|c|}
\hline Kode & $\begin{array}{l}\text { kode } \\
\text { Board }\end{array}$ & 2013 & 2014 & 2015 \\
\hline MAGP & $\mathbf{P}$ & 100 & 50 & 50 \\
\hline UNSP & $\mathrm{U}$ & 50 & 50 & 50 \\
\hline CPRO & $\mathrm{U}$ & 50 & 103 & 50 \\
\hline $\mathrm{GZCO}$ & $\mathbf{U}$ & 110 & 135 & 95 \\
\hline DSFI & $\mathrm{U}$ & 51 & 200 & 106 \\
\hline GOLL & $\mathbf{P}$ & 251 & 74 & 120 \\
\hline BWPT & $\mathbf{U}$ & 1,330 & 400 & 138 \\
\hline JAWA & $\mathrm{U}$ & 380 & 378 & 220 \\
\hline SIMP & $\mathbf{U}$ & 780 & 705 & 332 \\
\hline PAIM & $\mathbf{P}$ & 360 & 480 & 425 \\
\hline TBLAA & $\mathrm{U}$ & 470 & 755 & 510 \\
\hline DSNG & $\mathrm{U}$ & 2,050 & 3,850 & 600 \\
\hline LSIP & U & 1,930 & 1,890 & 1,320 \\
\hline BISI & U & 560 & 790 & 1,350 \\
\hline BTEK & $\mathbf{P}$ & 1,264 & 1,048 & 1,497 \\
\hline ANJT & $\mathrm{U}$ & 1,490 & 1,325 & 1,610 \\
\hline SGRO & $\mathrm{U}$ & 2,000 & 2,100 & 1,700 \\
\hline SSMS & $\mathrm{U}$ & 820 & 1,665 & 1,950 \\
\hline IIKP & $\mathbf{P}$ & 2,200 & 3,340 & 3,675 \\
\hline SMLAR & $\mathbf{P}$ & 7,850 & 8,100 & 4,200 \\
\hline A.ALI & $\mathbf{U}$ & 25,100 & 24,250 & 15,850 \\
\hline
\end{tabular}

Ditinjau dari sudut kinerja keuangan, saham sektor pertanian ini, dibagi menjadi dua kelompok. Kelompok pertama adalah kelompok perusahaan dengan harga saham tahun 2015 kurang dari Rp 500.- dan kelompok perusahaan dengan harga saham diatas Rp 500. Profil kinerja keungan tahun 2015 untuk saham kelompok pertama terekam dalam tabel berikut: 
Siti Atikah, Sapto Hendri BS., Intan R., Wirawan S., Bq. Rosyida DA: Kinerja Keuangan ...

Tabel 2. Kinerja Keuangan Perusahaan Sektor Pertanian (Bagian Pertama)

\begin{tabular}{|c|c|c|c|c|c|c|c|c|c|c|c|c|c|}
\hline \multicolumn{14}{|c|}{ TAHUN 2015} \\
\hline Kode & $\begin{array}{c}\text { HARGA } \\
\text { SHM }\end{array}$ & CR & ATO & DTA & DER & FL & GPM & NPM & ROE & ROA & EPS & PER & PBV \\
\hline MAGP & 50 & 0.14 & 0.09 & 0.30 & 0.43 & 1.43 & 2.23 & -91.69 & -12.09 & -8.44 & -8.48 & -6.87 & 0.52 \\
\hline UNSP & 50 & 0.18 & 0.12 & 0.80 & 4.04 & 5.04 & 25.41 & -25.60 & -15.42 & -3.06 & -76.88 & -1.33 & 0.20 \\
\hline CPRO & 50 & 1.00 & 0.99 & 0.78 & 3.58 & 4.58 & -60.66 & 0.20 & -60.66 & -13.23 & -29.66 & -1.69 & 1.02 \\
\hline GZCO & 95 & 1.26 & 0.10 & 0.46 & 0.86 & 1.86 & 22.46 & -6.47 & -0.19 & -0.64 & -5.12 & 18.56 & 0.21 \\
\hline DSFI & 106 & 1.50 & 1.84 & 0.53 & 1.11 & 2.11 & 11.89 & 2.43 & 9.46 & 4.48 & 7.29 & 8.36 & 1.38 \\
\hline GOLL & 120 & 0.82 & 0.06 & 0.57 & 1.35 & 2.35 & 22.00 & -12.72 & -1.20 & -0.76 & -3.64 & 20.31 & 0.29 \\
\hline BWPT & 138 & 0.71 & 0.15 & 0.62 & 1.65 & 2.65 & 21.46 & -6.78 & -2.33 & -1.03 & -5.70 & 24.20 & 0.65 \\
\hline JAWA & 220 & 0.45 & 0.20 & 0.17 & 0.96 & 2.61 & 22.32 & -1.78 & -0.91 & -0.35 & -3.13 & $\begin{array}{c}- \\
70.25\end{array}$ & 0.64 \\
\hline SIMP & 332 & 0.94 & 0.44 & 0.46 & 0.84 & 1.84 & 22.41 & 2.64 & 2.12 & 1.15 & 16.72 & 19.85 & 0.30 \\
\hline PALM & 425 & 0.23 & 0.22 & 0.64 & 1.78 & 2.78 & 31.29 & -5.28 & -3.27 & -1.18 & -7.75 & $\begin{array}{c}- \\
54.81 \\
\end{array}$ & 1.79 \\
\hline
\end{tabular}


Saham CPRO memiliki harga pasar yang terendah dibandingkan saham PALM, namun memiliki rasio lancar (CR) dan tingkat perputaran aset (ATO) yang lebih tinggi. Hanya tiga saham saja yang memiliki rasio lancar diatas 1,00, yaitu CPRO, GZCO dan DSFI. Artinya, ketiga saham memiliki kemampuan membayar hutang lancarnya lebih tinggi dibandingkan perusahaan lainnya. Rasio lancar di sektor pertanian mencapai 1.19 poin, yang berarti bahwa saham GZCO dan DSFI memiliki rasio lancar diatas ratarata industrinya. Kemampuan perusahaan DSFI untuk menghasilkan penjualan bersih dari setiap rupiah nilai asetnya lebih tinggi dibandingkan rata-rata industrinya. Tingkat perputaran aset di sektor pertanian sebesar 0.47 kali, sehingga CPRO dan DSFI lebih efisien dalam menghasilkan pendapatan.

Lebih dari 5 perusahaan pada kelompok pertama memiliki rasio utang yang lebih tinggi dibandingkan rata-rata industri. Rata-rata industri untuk rasio hutang terhadap aset dan ekuitas perusahaan, masing-masing sebesar 0.49 kali dan 1.71 kali. Kreditur, secara umum, menyukai perusahaan dengan tingkat utang yang rendah dibandingkan rata-rata industrinya.

Kemampuan perusahaan dikelompok pertama untuk menghasilkan harga pokok penjualan yang rendah tergolong baik, meskipun laba setelah pajaknya menjadi negatif. Hal ini dilihat dari perolehan marjin laba (GPM) yang positif, meskipun laba setelah pajak menjadi negatif. Kondisi ini diperlihatkan oleh rasio marjin laba setelah pajak (NPM), tingkat pengembalian (ROA, ROE dan PER), laba per saham (EPS) yang negatif. Dalam hal ini, investor belum bersedia untuk mengorbankan satu rupiah dana yang dimilikinya untuk membeli saham perusahaan kelompok pertama ini.

Saham sektor pertanian yang termasuk dalam kelompok pertama, tergolong kedalam kelompok saham yang murah. Hal ini tidak dilihat dari harga pasar sahamnya yang kurang dari Rp 500 per lembar, namun ditinjau juga dari sisi fundamental perusahaan, antara lain: PER dan PBV yang rendah atau kecil ( (Liembono and Mulyana 2016).

Kelompok kedua dalam saham sektor pertanian terdiri 11 (sebelas) perusahaan dengan harga pasar saham per 31 Desember 2015 tercatat antara Rp 500 sampai dengan Rp 16.000. Profil harga saham dan kinerja keuangan saham kelompok kedua ini sebagai berikut: 
Siti Atikah, Sapto Hendri BS., Intan R., Wirawan S., Bq. Rosyida DA: Kinerja Keuangan ...

Tabel 3. Kinerja Keuangan Perusahaan Sektor Pertanian (Bagian kedua)

TAHUN 2015

\begin{tabular}{|c|c|c|c|c|c|c|c|c|c|c|c|c|c|}
\hline \multicolumn{14}{|c|}{ TAHUN 2015} \\
\hline Kode & HARGA SHM & $\mathrm{CR}$ & ATO & DTA & DER & $\mathrm{FL}$ & GPM & NPM & ROE & ROA & EPS & PER & PBV \\
\hline TBLA & 510 & 1.16 & 0.57 & 0.69 & 2.23 & 3.23 & 21.95 & 3.77 & 6.98 & 2.16 & 36.88 & 13.83 & 0.95 \\
\hline DSNG & 600 & 1.10 & 0.56 & 0.68 & 2.13 & 3.13 & 26.55 & 6.84 & 12.07 & 3.85 & 1182.72 & 23.58 & 2.54 \\
\hline LSIP & 1,320 & 2.22 & 0.47 & 0.17 & 0.21 & 1.21 & 26.63 & 14.88 & 8.49 & 7.04 & 91.36 & 14.45 & 1.23 \\
\hline BISI & 1,350 & 6.37 & 0.67 & 0.15 & 0.18 & 117.98 & 39.10 & 18.36 & 14.54 & 12.33 & 87.97 & 15.35 & 2.23 \\
\hline BTEK & 1,497 & 0.49 & 0.10 & 0.84 & 5.20 & 6.20 & 29.65 & 0.55 & 0.34 & 0.05 & 0.46 & 3896.69 & 24.85 \\
\hline ANJT & 1,610 & 0.92 & 0.28 & 0.28 & 3.82 & 1.38 & 0.42 & -6.29 & -2.46 & -1.78 & -36.12 & 60.37 & 1.45 \\
\hline SGRO & 1,700 & 1.27 & 0.41 & 0.36 & 1.13 & 2.13 & 27.79 & 8.53 & 7.49 & 3.51 & 130.99 & 12.98 & 0.94 \\
\hline SSMS & 1,950 & 1.33 & 0.34 & 0.56 & 1.30 & 2.30 & 52.61 & 24.75 & 19.35 & 8.42 & -2.75 & 33.11 & 6.12 \\
\hline IIKP & 3,675 & 1.01 & 0.06 & 0.04 & 0.04 & 1.04 & -49.62 & -80.94 & -5.06 & -4.86 & -4.86 & -765.21 & 38.69 \\
\hline SMAR & 4,200 & 1.08 & 1.51 & 0.68 & 2.14 & 3.05 & 10.87 & -1.06 & -5.06 & -1.61 & -134.45 & -31.24 & 1.58 \\
\hline AALI & 15,850 & 0.80 & 0.61 & 0.46 & 0.84 & 1.84 & 23.60 & 5.33 & 5.95 & 3.23 & 393.15 & 40.32 & 2.13 \\
\hline
\end{tabular}


Jawara harga saham tertinggi di sektor pertanian, AALI, memiliki rasio likuiditas dan rasio utang lebih rendah dari rata-rata industri. Meskipun harga pasar sahamnya mengalami penurunan dalam tiga tahun terakhir, harga pasar saham AALI masih bertahan diatas Rp 15.000. Pihak pengelola AALI mampu menggunakan dana tunai maupun dana pinjaman dengan tepat. Salah satu bentuk pengelolaan tersebut ditinjau dari kemampuan menggunakan aset untuk memperoleh pendapatan yang tinggi.

Rasio likuiditas tertinggi terdapat pada saham LSIP, sebesar 2.22. Berbeda dengan AALI, pihak manajemen LSIP masih mengelola aset lancarnya dalam bentuk kas dan setara kas, piutang serta persediaan barang dagang. Saham BTEK, IIKP, SSMS, SGRO dan ANJT belum mampu untuk mengelola aset mereka secara efisien untuk menghasilkan pendapatan. Hal ini diketahui dari rasio perputaran aset mereka yang lebih rendah dibandingkan rata-rata industri.

Probabilita investor untuk membeli saham IIKP cenderung rendah. Ini ditinjau dari rasio profitabilitas, antara lain: gross profit margin, return on asset dan return on equity, saham IIKP yang negatif sejak tahun 2013. Hal serupa terjadi pada saham SMAR di tahun 2015. Kedua saham juga memiliki rasio laba per lembar saham (EPS dan PER) yang negatif, namun keistimewaan keduanya, adalah rasio nilai buku saham per lembarnya yang cukup tinggi.

\section{Kinerja Keuangan Perusahaan Sektor Pertambangan}

Sektor pertambangan terdiri dari 42 perusahaan, namun terdapat 9 perusahaan yang tidak memiliki kelengkapan data sehingga tidak diolah lebih lanjut. Profil harga pasar saham dari sektor ini tampak pada tabel 4.3.

Tabel 4. Harga Pasar Saham Sektor Pertambangan Periode 2013-2015

\begin{tabular}{|l|l|l|l|l|l|l|r|r|r|}
\hline \multicolumn{4}{|c|}{$\begin{array}{c}\text { HARGA SAHAM SEKTOR } \\
\text { PERTAMBANGAN }\end{array}$} & \multicolumn{5}{c|}{ HARGA SAHAM SEKTOR } \\
\hline No. & Kode & \multicolumn{1}{|c|}{2013} & 2014 & 2015 & No. & Kode & 2013 & 2014 & 2015 \\
\hline 1 & ADRO & 1,090 & 1,040 & 515 & 18 & TOBA & 740 & 920 & 675 \\
\hline 2 & ARII & 850 & 448 & 400 & 19 & ELSA & & 685 & \\
& & & & & & & 330 & & 247 \\
\hline 3 & ATPK & 124 & 270 & 209 & 20 & ESSA & 2,375 & 2,995 & 1,650 \\
\hline 4 & BSSR & 1,950 & 1,590 & 1,110 & 21 & MEDC & 2,100 & 3,800 & 795 \\
\hline 5 & BUMI & 300 & 80 & 50 & 22 & PKPK & 86 & 88 & 50 \\
\hline 6 & BYAN & 8,500 & 6,650 & 7,875 & 23 & RUIS & 192 & 217 & 215 \\
\hline 7 & DEWA & 50 & 50 & 50 & 24 & ANTM & 1,090 & 1,065 & 314 \\
\hline 8 & DOID & 92 & 193 & 54 & 25 & CITA & 390 & 940 & 940 \\
\hline 9 & DSSA & 13,500 & 12,900 & 12,100 & 26 & CKRA & 215 & 199 & 50 \\
\hline
\end{tabular}


Siti Atikah, Sapto Hendri BS., Intan R., Wirawan S., Bq. Rosyida DA: Kinerja Keuangan ...

\begin{tabular}{|l|l|l|l|l|l|l|r|r|r|}
\hline \multicolumn{3}{|c|}{$\begin{array}{c}\text { HARGA SAHAM SEKTOR } \\
\text { PERTAMBANGAN }\end{array}$} & \multicolumn{5}{c|}{ HARGA SAHAM SEKTOR } \\
\hline 10 & GEMS & 2,175 & 2,000 & 1,400 & 27 & DKFT & 380 & 397 & 397 \\
\hline 11 & HRUM & 2,750 & 1,660 & 675 & 28 & INCO & 2,650 & 3,625 & 1,635 \\
\hline 12 & ITMG & 28,500 & 15,375 & 5,725 & 29 & PSAB & 2,400 & 540 & 1,370 \\
\hline 13 & KKGI & 2,050 & 1,005 & 420 & 30 & SMRU & 350 & 264 & 238 \\
\hline 14 & MYOH & 490 & 458 & 525 & 31 & TINS & 1,600 & 1,230 & 505 \\
\hline 15 & PTBA & 10,200 & 12,500 & 4,525 & 32 & CTTH & 64 & 67 & 56 \\
\hline 16 & PTRO & 1,150 & 925 & 290 & 33 & MITI & 75 & 185 & 124 \\
\hline 17 & SMMT & 1,686 & 1,785 & 171 & \multicolumn{7}{c|}{} \\
\hline \multicolumn{4}{|c|}{ Sumber: }
\end{tabular}

Harga pasar saham di sektor pertambangan cenderung menurun pada periode 2013 hingga 2015. Saham ITMG, DSSA, PTBA, GEMS, KKGI, INCO, PSAB, TINS, ESSA, SMMT dan ANTM mengalami penurunan drastis. Penurunan harga saham ANTM misalnya, dipicu oleh menurunnya perolehan laba bersih di kuartal pertama ahun 2015 karena adanya larangan ekspor mineral mentah, menurunnya harga komoditas dan kondisi ekonomi China yang memburuk. Saham ANTM turun sebesar $28 \%$.

Kinerja keuangan perusahaan di sektor pertambangan secara berturutturut diuraikan dalam beberapa bagian. Bagian pertama, dikelompokkan pada perusahaan yang memiliki harga pasar saham per 31 Desember 2015 berada pada kisaran kurang dari Rp 500. Kinerja mereka sebagai berikut:

Tabel 5. Likuiditas dan Solvabilitas Kelompok Pertama Sektor Pertambangan

\begin{tabular}{|c|l|r|r|r|r|r|r|}
\hline $\begin{array}{c}\text { No } \\
\cdot\end{array}$ & Kode & $\begin{array}{c}\text { Harga } \\
\text { Saham }\end{array}$ & $\begin{array}{c}\text { Current } \\
\text { Ratio }\end{array}$ & $\begin{array}{c}\text { Asset } \\
\text { Turn } \\
\text { Over }\end{array}$ & $\begin{array}{c}\text { Debt To } \\
\text { Total } \\
\text { Asset }\end{array}$ & $\begin{array}{r}\text { Debt to } \\
\text { Equity } \\
\text { Ratio }\end{array}$ & $\begin{array}{r}\text { Financial } \\
\text { Leverage }\end{array}$ \\
\hline 1 & BUMI & 50 & 0.10 & 0.01 & 1.86 & -2.17 & -1.17 \\
\hline 2 & DEWA & 50 & 1.25 & 0.64 & 0.40 & 0.66 & 1.66 \\
\hline 3 & PKPK & 50 & 0.81 & 0.12 & 0.51 & 1.04 & 2.04 \\
\hline 4 & CKRA & 50 & 7.54 & 0.02 & 0.04 & 0.04 & 1.04 \\
\hline 5 & DOID & 54 & 3.00 & 0.68 & 0.90 & 8.79 & 9.79 \\
\hline 6 & CTTH & 56 & 1.88 & 0.36 & 0.52 & 1.10 & 2.10 \\
\hline 7 & MITI & 124 & 1.86 & 0.13 & 0.55 & 1.24 & 2.24 \\
\hline 8 & SMMT & 171 & 0.76 & 0.04 & 0.44 & 0.79 & 1.79 \\
\hline 9 & ATPK & 209 & 3.26 & 0.14 & 0.43 & 0.76 & 1.76 \\
\hline 10 & RUIS & 215 & 0.87 & 1.46 & 0.69 & 2.23 & 3.23 \\
\hline 11 & SMRU & 238 & 1.47 & 0.14 & 0.51 & 1.04 & 2.04 \\
\hline 12 & ELSA & 247 & 1.44 & 0.86 & 0.40 & 0.67 & 1.67 \\
\hline
\end{tabular}




\begin{tabular}{|c|l|c|r|r|r|r|r|}
\hline $\begin{array}{c}\text { No } \\
\cdot\end{array}$ & Kode & $\begin{array}{c}\text { Harga } \\
\text { Saham }\end{array}$ & $\begin{array}{c}\text { Current } \\
\text { Ratio }\end{array}$ & $\begin{array}{c}\text { Asset } \\
\text { Turn } \\
\text { Over }\end{array}$ & $\begin{array}{c}\text { Debt To } \\
\text { Total } \\
\text { Asset }\end{array}$ & $\begin{array}{c}\text { Debt to } \\
\text { Equity } \\
\text { Ratio }\end{array}$ & $\begin{array}{r}\text { Financial } \\
\text { Leverage }\end{array}$ \\
\hline 13 & PTRO & 290 & 1.55 & 0.49 & 0.58 & 1.39 & 2.39 \\
\hline 14 & ANTM & 314 & 2.59 & 0.35 & 0.40 & 0.66 & 1.66 \\
\hline 15 & DKFT & 397 & 20.17 & 0.00 & 0.04 & 0.04 & 1.04 \\
\hline 16 & ARII & 400 & 0.21 & 0.08 & 0.77 & 3.29 & 4.29 \\
\hline 17 & KKGI & 420 & 2.22 & 1.13 & 0.22 & 0.28 & 1.28 \\
\hline
\end{tabular}

Sumber: www.idx.co.id, diolah.

Meskipun harga pasar saham mengalami penurunan, 98\% perusahaan masih memiliki kemampuan untuk membayar utang lancarnya. Hal ini terlihat dari rasio aset lancar tiga belas saham pada tabel 4.4 mencapai lebih dari $100 \%$. Jika dibandingkan dengan rata-rata industri, sebesar 2.49 persen, hanya lima saham perusahaan yang rasio lancarnya berada diatas rata-rata.

Rasio hutang dibandingkan nilai aset untuk industri pertambangan sebesar 0.49 , sementara rasio hutang terhadap ekuitas perusahaan sebesar 1,19, dan perbandingan antara aset dengan ekuitas perusahaan sebesar 3.32. Saham BUMI, sejak tahun 2014, memiliki nilai harga saham penutupan yang rendah, dibawah rata-rata harga saham industri pertambangan dan rata-rata harga saham gabungan di Bursa Efek Indonesia (BEI). Perusahaan yang berada dalam lingkungan Bakrie Group ini, memiliki ratio hutang yang negatif. Hal ini diakibatkan oleh nilai ekuitas yang menurun.

Harga pasar saham yang rendah memiliki arah yang positif dengan kemampuan perusahaan untuk menghasilkan pendapatan dan menekan harga pokok penjualan perusahaan. Terdapat tiga perusahaan yang memiliki tingkat rasio perputaran aset diatas rata-rata industri sebesar 53 persen. Namun jika aset perusahaan diperoleh dengan cara berhutang, akan menambah beban tetap perusahaan dan dapat mengurangi laba usaha. Kondisi ini terlihat dari rasio utang (DER dan DTA) yang tinggi berakibat pada rasio marjin laba operasi yang rendah.

Meskipun harga pasar saham pertambangan di kelompok pertama relatif terjangkau, investor masih enggan untuk menanamkan modalnya pada saham ke 15 perusahaan. Hal ini diindikasikan dengan rasio laba yang negatif sebagaimana ditunjukkan oleh tabel 4.5 berikut. 
Siti Atikah, Sapto Hendri BS., Intan R., Wirawan S., Bq. Rosyida DA: Kinerja Keuangan ...

Tabel 6. Rasio Profitabilitas dan Laba Per Saham Sektor Pertambangan

\begin{tabular}{|r|l|l|r|r|r|r|r|r|}
\hline No. & Kode & $\begin{array}{c}\text { Harga } \\
\text { Saham }\end{array}$ & $\begin{array}{c}\text { Gross } \\
\text { Profit } \\
\text { Margin }\end{array}$ & $\begin{array}{c}\text { Net } \\
\text { Profit } \\
\text { Margin }\end{array}$ & $\begin{array}{c}\text { Return } \\
\text { On } \\
\text { Equity }\end{array}$ & $\begin{array}{c}\text { Return } \\
\text { On } \\
\text { Asset }\end{array}$ & $\begin{array}{c}\text { Earning } \\
\text { Per } \\
\text { Share }\end{array}$ & $\begin{array}{c}\text { Price } \\
\text { Earning } \\
\text { Ratio }\end{array}$ \\
\hline 1 & BUMI & 50 & 100.00 & 5395.38 & 75.23 & -64.39 & 725.12 & -0.15 \\
\hline 2 & DEWA & 50 & 9.95 & 0.19 & 0.21 & 0.12 & 0.06 & 166.36 \\
\hline 3 & PKPK & 50 & -185.17 & -311.70 & -73.89 & -36.17 & 100.87 & -0.49 \\
\hline 4 & CKRA & 50 & 11.59 & -247.18 & -5.80 & -5.56 & -8.24 & -6.70 \\
\hline 5 & DOID & 54 & 22.25 & -1.47 & -9.77 & -1.00 & -14.77 & -3.90 \\
\hline 6 & CTTH & 56 & 33.47 & 0.88 & 0.67 & 0.32 & 1.58 & 35.35 \\
\hline & & & & & - & & - & \\
7 & MITI & 124 & -100.78 & -572.30 & 161.89 & -72.13 & 136.70 & -0.91 \\
\hline 8 & SMMT & 171 & 0.77 & -210.56 & -15.18 & -8.50 & -15.93 & -10.74 \\
\hline 9 & ATPK & 209 & -31.89 & -65.48 & -16.00 & -9.11 & -28.05 & -6.92 \\
\hline 10 & RUIS & 215 & 18.63 & 2.58 & 12.20 & 3.78 & 53.61 & 4.01 \\
\hline 11 & SMRU & 238 & 4.10 & -27.98 & -8.00 & -3.93 & -9.72 & -27.10 \\
\hline 12 & ELSA & 247 & 19.04 & 10.06 & 14.41 & 8.62 & 51.43 & 4.80 \\
\hline 13 & PTRO & 290 & 14.09 & -6.14 & -7.12 & -2.98 & 184.83 & -1.67 \\
\hline 14 & ANTM & 314 & 1.85 & -13.68 & -7.87 & -4.75 & -59.96 & -5.24 \\
\hline 15 & DKFT & 397 & 0.00 & 0.00 & -2.50 & -2.39 & -5.34 & -74.36 \\
\hline 16 & ARII & 400 & -27.31 & -91.46 & -31.61 & -7.38 & 122.75 & -3.46 \\
\hline 17 & KKGI & 420 & 23.85 & 5.89 & 7.39 & 5.76 & 83.80 & 5.33 \\
\hline
\end{tabular}

Sumber: www.idx.co.id, diolah.

Bagaimana dengan saham 18 perusahaan sektor pertambangan lainnya? Berikut adalah profil likuiditas mereka:

Tabel 7. Likuiditas dan Solvabilitas Kelompok Kedua Sektor Pertambangan

\begin{tabular}{|r|l|c|c|c|c|c|r|}
\hline No. & Kode & $\begin{array}{c}\text { Harga } \\
\text { Saham }\end{array}$ & $\begin{array}{c}\text { Current } \\
\text { Ratio }\end{array}$ & $\begin{array}{c}\text { Asset } \\
\text { Turn } \\
\text { Over }\end{array}$ & $\begin{array}{c}\text { Debt } \\
\text { Total } \\
\text { Asset }\end{array}$ & $\begin{array}{c}\text { Debt } \\
\text { Equity } \\
\text { Ratio }\end{array}$ & $\begin{array}{c}\text { Financial } \\
\text { Leverage }\end{array}$ \\
\hline 18 & TINS & 505 & 1.82 & 0.74 & 0.42 & 0.73 & 1.73 \\
\hline 19 & ADRO & 515 & 2.40 & 0.45 & 0.44 & 0.78 & 1.78 \\
\hline 20 & MYOH & 525 & 2.33 & 1.40 & 0.42 & 0.73 & 1.73 \\
\hline 21 & HRUM & 675 & 6.91 & 0.66 & 0.10 & 0.11 & 38.1 \\
\hline 22 & TOBA & 675 & 1.40 & 1.23 & 0.45 & 0.82 & 1.82 \\
\hline
\end{tabular}




\begin{tabular}{|r|l|c|c|c|c|r|r|}
\hline No. & Kode & $\begin{array}{c}\text { Harga } \\
\text { Saham }\end{array}$ & $\begin{array}{c}\text { Current } \\
\text { Ratio }\end{array}$ & $\begin{array}{c}\text { Asset } \\
\text { Turn } \\
\text { Over }\end{array}$ & $\begin{array}{c}\text { Debt } \\
\text { Total } \\
\text { Asset }\end{array}$ & $\begin{array}{c}\text { Debt } \\
\text { Equity } \\
\text { Ratio }\end{array}$ & $\begin{array}{c}\text { Financial } \\
\text { Leverage }\end{array}$ \\
\hline 23 & MEDC & 795 & 1.98 & 0.22 & 0.76 & 3.15 & 4.15 \\
\hline 24 & CITA & 940 & 0.75 & 0.00 & 0.54 & 1.16 & 2.16 \\
\hline 25 & BSSR & 1,110 & 0.84 & 1.49 & 0.40 & 0.66 & 1.66 \\
\hline 26 & PSAB & 1,370 & 0.29 & 0.35 & 0.62 & 1.61 & 2.61 \\
\hline 27 & GEMS & 1,400 & 0.28 & 0.96 & 0.33 & 0.49 & 1.49 \\
\hline 28 & INCO & 1,635 & 4.04 & 0.34 & 0.20 & 0.25 & 1.25 \\
\hline 29 & ESSA & 1,650 & 1.60 & 0.15 & 0.34 & 0.52 & 1.52 \\
\hline 30 & PTBA & 4,525 & 1.54 & 0.81 & 0.45 & 0.82 & 1.82 \\
\hline 31 & ITMG & 5,725 & 1.80 & 1.35 & 0.29 & 0.41 & 1.55 \\
\hline 32 & BYAN & 7,875 & 1.89 & 0.50 & 0.82 & 4.45 & 5.45 \\
\hline 33 & DSSA & 12,100 & 1.53 & 0.29 & 0.47 & 0.89 & 1.89 \\
\hline
\end{tabular}

Sumber: www.idx.co.id, diolah

Harga saham tertinggi di sektor pertambangan diraih oleh DSSA, anak perusahaan dari PT. Sinar Mas Tunggal. Pesaing terdekat dari harga pasar saham adalah BYAN dan ITMG. Harga saham ITMG menurun pada periode 2015, dari harga Rp28.500 tahun 2013 dan Rp 15.375 tahun 2014. Harga saham ITMG ditutup dengan manis, ke harga Rp 16.875 di akhir Desember 2016, dan meningkat per 28 November 2017 sebesar Rp 19.800 per lembar. Laba ITMG kuartal ke III tahun 2017 meningkat sebesar 148\% (Kontan 2017).

Rasio likuiditas dan solvabilitas kelompok kedua saham industri pertambangan cukup baik, meskipun harga sahamnya beragam. Harga saham terendah dalam kelompok kedua ini adalah emiten dengan kode TINS. Ini adalah kode saham untuk PT. Timah, badan usaha pertambangan yang 65\% sahamnya dimiliki oleh Pemerintah Republik Indonesia. Harga saham TINS berfluktuasi, dan per 31 Desember 2016 ditutup dengan harga diatas Rp 1000,-.

Profil profitabilitas saham-saham yang terdaftar di sektor pertambangan kelompok kedua tampak sebagai berikut: 
Siti Atikah, Sapto Hendri BS., Intan R., Wirawan S., Bq. Rosyida DA: Kinerja Keuangan ...

Tabel 8. Profil Profitabilitas Kelompok Kedua Saham Sektor Pertambangan

\begin{tabular}{|c|l|c|r|r|r|r|r|r|}
\hline No. & Kode & HS & GPM & \multicolumn{1}{c|}{ NPM } & \multicolumn{1}{c|}{ ROE } & \multicolumn{1}{c|}{ ROA } & \multicolumn{1}{c|}{ EPS } & \multicolumn{1}{c|}{ PER } \\
\hline 18 & TINS & 505 & 9.98 & 1.48 & 1.89 & 1.09 & 13.64 & 37.03 \\
\hline 19 & ADRO & 515 & 20.24 & 5.63 & 4.50 & 2.53 & 65.74 & 7.83 \\
\hline 20 & MYOH & 525 & 18.68 & 10.93 & 26.50 & 15.34 & 163.99 & 3.4 \\
\hline 21 & HRUM & 675 & 18.39 & -7.62 & -5.53 & -4.99 & -104.33 & -6.87 \\
\hline 22 & TOBA & 675 & 20.23 & 7.38 & 16.58 & 9.11 & 82.71 & 8.67 \\
\hline 23 & MEDC & 795 & 33.14 & -29.62 & -26.54 & -6.40 & -800.03 & -1.02 \\
\hline 24 & CITA & 940 & 20.63 & -2454.12 & -26.41 & -12.20 & -101.17 & -9.29 \\
\hline 25 & BSSR & 1,110 & 34.15 & 10.18 & 25.13 & 15.17 & 147.75 & 7.98 \\
\hline 26 & PSAB & 1,370 & 51.98 & 10.91 & 9.86 & 3.77 & 67.07 & 21.71 \\
\hline 27 & GEMS & 1,400 & 31.22 & 0.59 & 0.84 & 0.57 & 5.03 & 296.03 \\
\hline 28 & INCO & 1,635 & 14.99 & 6.39 & 2.75 & 2.21 & 74.49 & 23.32 \\
\hline 29 & ESSA & 1,650 & 42.18 & 12.03 & 2.66 & 1.75 & 69.87 & 25.09 \\
\hline 30 & PTBA & 4,525 & 30.14 & 14.83 & 21.93 & 12.06 & 883.59 & 5.12 \\
\hline 31 & ITMG & 5,725 & 22.04 & 3.97 & 7.56 & 5.36 & 818.60 & 7.43 \\
\hline 32 & BYAN & 7,875 & 26.40 & -17.59 & -47.51 & -8.72 & -283.18 & -29.55 \\
\hline 33 & DSSA & 12,100 & 26.38 & -1.34 & -0.73 & -0.39 & -99.67 & -129.00 \\
\hline
\end{tabular}

Sumber: www.idx.co.id, diolah

Harga saham yang tinggi tidak berarti mampu memberikan tingkat laba yang tinggi pada periode berjalan. Hal ini tampak pada kode emiten BYAN, DSSA, CITA, MEDC, dan HRUM. Laba bersih keempat perusahaan pada tahun 2015 menurun bahkan merugi. Kerugian ini disebabkan oleh tingginya beban operasional perusahaan.

\section{Hubungan Kinerja Keuangan dengan Harga Saham Sektor Pertambangan}

Hubungan antara variabel-variabel kinerja keuangan dengan harga saham perusahaan pertambangan, tampak sebagai berikut: 
Tabel 9. Hasil Uji Anova Sektor Pertambangan

\begin{tabular}{|c|c|c|c|c|c|c|c|}
\hline \multirow[b]{2}{*}{ Model } & \multicolumn{2}{|c|}{$\begin{array}{l}\text { Unstandardized } \\
\text { Coefficients }\end{array}$} & \multirow{2}{*}{\begin{tabular}{|c|}
$\begin{array}{c}\text { Standardiz } \\
\text { ed } \\
\text { Coefficient } \\
\text { s }\end{array}$ \\
Beta \\
\end{tabular}} & \multirow[b]{2}{*}{$\mathrm{t}$} & \multirow[b]{2}{*}{ Sig. } & \multicolumn{2}{|c|}{$\begin{array}{l}\text { Collinearity } \\
\text { Statistics }\end{array}$} \\
\hline & B & $\begin{array}{l}\text { Std. } \\
\text { Error }\end{array}$ & & & & $\begin{array}{c}\text { Toleranc } \\
\mathrm{e}\end{array}$ & VIF \\
\hline $\begin{array}{ll}1 & \text { (Constant) }\end{array}$ & 2.736 & .197 & & 13.903 & .000 & & \\
\hline CR & -.003 & .008 & -.054 & -.419 & .676 & .503 & 1.9 \\
\hline ATO & .092 & .153 & .067 & .599 & .551 & .656 & 1.5 \\
\hline DTA & .203 & .362 & .070 & .561 & .577 & .535 & 1.87 \\
\hline DER & -.119 & .047 & -.615 & -2.545 & .013 & .142 & 7.05 \\
\hline $\mathrm{FL}$ & .015 & .015 & .116 & 1.003 & .319 & .617 & 1.6 \\
\hline GPM & .000 & .001 & .028 & .279 & .781 & .791 & 1.26 \\
\hline NPM & .000 & .000 & -.043 & -.418 & .677 & .795 & 1.2 \\
\hline ROE & -.017 & .006 & -.889 & -3.092 & .003 & .100 & 9.9 \\
\hline ROA & .052 & .014 & .925 & 3.802 & .000 & .140 & 7.1 \\
\hline EPS & $-3.518 \mathrm{E}-6$ & .000 & -.024 & -.215 & .830 & .683 & 1.4 \\
\hline PER & $-5.055 E-6$ & .000 & -.040 & -.332 & .741 & .557 & 1.7 \\
\hline
\end{tabular}

Hasil uji menunjukkan model persamaan linear antara kinerja keuangan dengan harga saham sebagai berikut (standardized beta):

$\mathrm{HS}=-0054 \mathrm{CR}+0.067 \mathrm{ATO}+0.070 \mathrm{DTA}-0.615 \mathrm{DER}+0.116 \mathrm{FL}+0.028 \mathrm{GPM}-$

$0.043 \mathrm{NPM}-0.889 \mathrm{ROE}+0.925 \mathrm{ROA}-0.215 \mathrm{EPS}-$

0.332 PER (persamaan 1)

Berdasarkan model persamaan tersebut, tampak bahwa rasio aset lancar (CR), rasio utang terhadap ekuitas (DER), rasio laba bersih (NPM), rasio laba terhadap ekuitas (ROE), rasio laba per lembar saham (EPS) dan rasio harga saham (PER) memiliki arah yang negatif dengan harga saham. Dengan demikian, pada saat variabel CR, DER, NPM. ROA, ROE, EPS dan PER mengalami peningkatan satu satuan, harga saham diprediksi akan menurun, dan sebaliknya. Sementara variabel lainnya, memiliki arah yang positif dengan harga saham. Berdasarkan tabel 4.8. dapat diketahui hanya variabel DER, ROE dan ROA yang mampu mempengaruhi harga saham.

Model persamaan pertama dapat dikatakan sebagai model yang baik. Hal ini dilihat dari tingkat signifikansi model yang lebih kecil dari 0.05 
Siti Atikah, Sapto Hendri BS., Intan R., Wirawan S., Bq. Rosyida DA: Kinerja Keuangan ...

Tabel 10. Hasil Uji Fit model

\begin{tabular}{|l|l|l|l|l|}
\hline Uji F & Sig. F & R square & Adjusted R Square & Durbin Watson \\
\hline 3.159 & 0.001 & 0.288 & 0.197 & 2.119 \\
\hline
\end{tabular}

Sumber: data diolah

Model persamaan pertama mengukur hubungan antara variabel-variabel dalam kinerja keuangan dengan harga saham. Hasil analisis menunjukkan bahwa model pertama ini mampu menerangkan kemampuan variabel kinerja keuangan terhadap harga saham cukup terbatas, yaitu sebesar 28,8 persen. Masih banyak faktor lain yang mempengaruhi harga saham, seperti tingkat suku bunga, politik dan sebagainya.Model pertama ini telah memenuhi unsur utama yang mendasari model linear regresi, yaitu telah memenuhi unsur normalitas, bebas multikolinieritas, heterokedastisitas dan autokorelasi sebagaimana tampak pada tabel 9, tabel 10, dan tabel 11 berikut:

Tabel 11. Hasil uji heterokedastisitas

\begin{tabular}{|c|r|r|}
\hline Model & \multicolumn{1}{|c|}{$\mathrm{t}$} & \multicolumn{1}{l|}{ Sig. } \\
\hline 1 (Constant) & 4.344 & .000 \\
CR & -.707 & .482 \\
ATO & -.858 & .393 \\
DTA & .919 & .361 \\
DER & -1.507 & .135 \\
FL & -.978 & .331 \\
GPM & .157 & .876 \\
NPM & 1.164 & .248 \\
ROE & -1.552 & .124 \\
ROA & 1.506 & .136 \\
EPS & .052 & .958 \\
PER & -.435 & .664 \\
\hline Kolmo!Smirnov Z & Unstandardize & .611 \\
\hline Asymp. Sig. (2-tailed) & Unstandardize & .849 \\
\hline
\end{tabular}

Sumber: data diolah 


\subsection{Hubungan Kinerja Keuangan dengan Harga Saham Sektor Pertanian}

Hubungan kinerja keuangan dan harga saham di sektor pertanian tahun 2013 sampai dengan 2015, tampak dalam model persamaan kedua berikut ini:

Tabel 12. Hasil uji Anova sektor pertanian

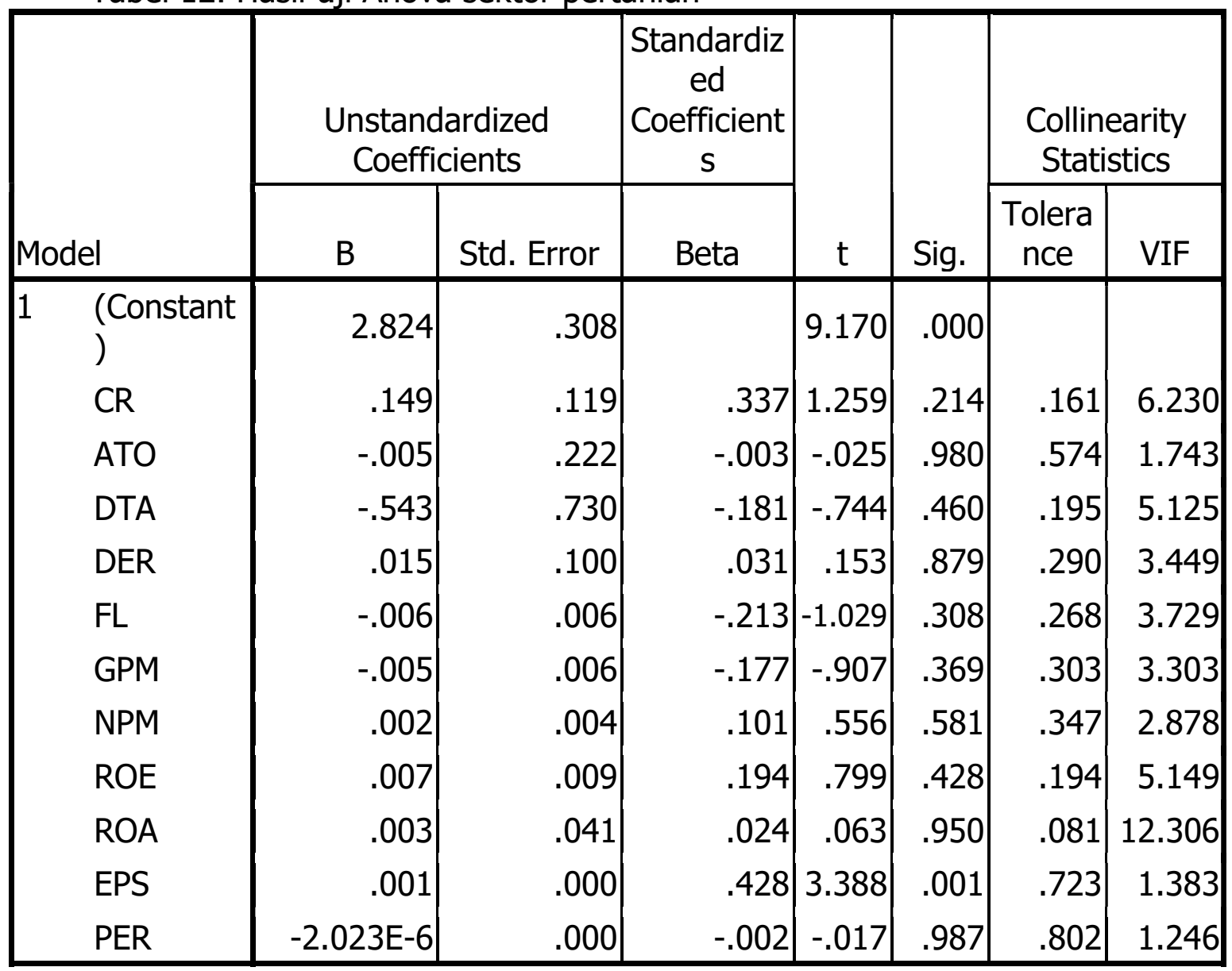

Sumber: data diolah

Berdasarkan tabel 4.11, model persamaan linear untuk hubungan antara kinerja keuangan dan harga saham sektor pertanian (standardized beta) adalah:

$\mathrm{HS}=0.337 \mathrm{CR}-0.003 \mathrm{ATO}-0.181 \mathrm{DTA}+0.031 \mathrm{DER}-0.213 \mathrm{FL}-0.177 \mathrm{GPM}+$ $0.101 \mathrm{NPM}+0.194 \mathrm{ROE}+0.024 \mathrm{ROA}+0.428 \mathrm{EPS}-0.002 \mathrm{PER}$

Persamaan kedua ini menunjukkan bahwa variabel ATO, DTA, FL, GPM dan PER memiliki arah yang negatif dengan harga saham di sektor pertanian. Variabel kinerja keuangan lainnya, yaitu CR, DER, NPM, ROA, ROE dan EPS memiliki arah positif. Bila ditinjau dari sisi signifikansi, hanya variabel EPS yang memenuhi unsur signifikan, yaitu kurang dari 0.05 . 
Siti Atikah, Sapto Hendri BS., Intan R., Wirawan S., Bq. Rosyida DA: Kinerja Keuangan ...

Model persamaan kedua dapat dikatakan sebagai model persamaan yang baik, yang ditunjukkan dengan hasil uji F (statistik) sebesar 3.347 dengan tingkat signifikansi sebesar 0.001. Nilai capaian tersebut menunjukkan bahwa seluruh variabel kinerja keuangan yang digunakan, secara simultan, mampu menjelaskan arah hubungan mereka terhadap harga saham. Namun, kekuatan menjelaskan hubungan variabel kinerja keuangan dengan harga saham cukup rendah, yakni sebesar 42,4 persen (R-square) atau menggunakan adjusted R-square sebesar 29.7 persen.

Meskipun mampu memenuhi unsur model yang baik, model persamaan kedua belum mampu lulus unsur pengujian asumsi klasik. Hasil uji kolmogorv-smirnov diperoleh nilai signifikansi sebesar 0.950 , sehingga dapat dinyatakan data yang dipergunakan dalam penelitian ini berdistribusi normal. Namun variabel yang digunakan tidak mampu memenuhi persyaratan linieritas lainnya, yaitu multikolinieritas dan heterokedastisitas. Hasil uji multikolinieritas diperoleh nilai VIF sebagian besar variabel independennya kurang dari 10. Hanya variabel ROA yang memiliki nilai VIF sebesar 12. Untuk variabel ATO, ROA, ROE dan EPS masing-masing memiliki signifikansi kurang dari 0.05 sehingga tidak memenuhi persyaratan uji multikolinieritas. Penelitian ini tidak melakukan perubahan atas data yang digunakan untuk memperbaiki hasil pengujian asumsi klasik. Hal ini dilakukan untuk memperoleh interpretasi dari data yang asli atau data awal.

\section{KESIMPULAN DAN REKOMENDASI}

\section{Simpulan}

Hasil penelitian ini sebagai berikut:

a. Pada kelompok perusahaan sektor pertanian dengan harga saham diakhir tahun 2015 kurang dari Rp 500, delapan dari sepuluh perusahaan memiliki tingkat NPM, ROE, ROA, EPS dan PER yang negatif.

b. Sebelas perusahaan sektor pertanian, diakhir tahun 2015, harga pasar saham mereka antara Rp 500 sampai dengan Rp 16.000. Tiga perusahaan memiliki tingkat NPM, ROE, ROA, PER dan EPS yang negatif, dan satu perusahaan dengan tingkat EPSnya saja yang negatif.

c. Tujuh belas perusahaan sektor pertambangan, diakhir tahun 2015, harga pasar saham mereka kurang dari Rp 500. Sebelas diantaranya memiliki tingkat NPM, ROE, ROA, EPS dan PER yang negatif, delapan perusahaan memiliki tingkat PER yang negatif, 3 perusahaan dengan 
tingkat GPM negatif, dan satu perusahaan dengan tingkat DER dan FL yang negatif.

d. Delapan belas perusahaan sektor pertambangan termasuk kelompok perusahaan dengan harga saham penutupan akhir tahun 2015 antara Rp 500 sampai dengan Rp 12.100. Hanya lima perusahaan memiliki tingkat NPM, ROE, ROA, EPS dan PER yang negatif.

e. Pada perusahaan sektor pertanian, tidak terbukti secara empiris bahwa CR, DER, NPM, ROE, EPS dan PER memiliki arah yang positif terhadap harga saham. Sementara itu variabel lainnya terbukti memiliki arah yang positif terhadap harga saham.

f. Pada perusahaan sektor pertambangan, terbukti secara empiris, bahwa CR, DER, NPM, ROE dan EPS memiliki arah yang positif terhadap harga saham. Sementara variabel lainnya memiliki arah yang negatif.

\section{Rekomendasi dan Keterbatasan}

Penelitian ini hanya melihat ritme dari kinerja keuangan terhadap harga saham, dengan mengabaikan unsur "mengapa". Oleh karena itu, bagi peneliti berikutnya atau bagi investor, dapat menganalisis keterkaitan faktor fundamental dengan harga saham dengan sudut pandang seorang "analis saham".

\section{DAFTAR PUSTAKA}

Ismail, Vinola Herawaty, and Kiki Munandar Witarno. "Analysis the Effect of Company's Fundamental Characteristics and Real Earnings Management to Stock Return Moderated by Audit Quality." OIDA International Journal of Sustainable Development, issn 1923-6654, eissn 19233-6662, 2014: 23-44.

Kamonye, Ben N. "The Relationship Between Equity Prices and Financial Performance of Commercial Banks Quoted on The Nairobi Securities Exchange." Thesis. University of Nairobi, erepository.uonbi.ac.ke, October 2012.

Kohansal, Mohammad Reza, Amir Dadrasmoghaddam, Komeil Mahjori Karmozdi, and Abolfazl Mohseni. "Relationship Between Financial Ratios and Stock Prices for the Food Industry Firms in Stock Exchange of Iran." World Applied Programming, vol (3), issue (10), October, issn 2222-2510, 2013: 512-521.

Liembono, RH, and A. Rudi Mulyana. Analisis Fundamental 2. Surabaya: PT. Menuju Insan Cemerlang, 2016. 
Siti Atikah, Sapto Hendri BS., Intan R., Wirawan S., Bq. Rosyida DA: Kinerja Keuangan ...

Olugbenga, Adaramola Anthony, and Oyerinde Adewale Atanda. "The Relationship Between Financial Accounting Information and Market Values of Quoted Firms in Nigeria." Global Journal of Contemporary Research in Accounting, Auditing and Business Ethics, vol (1), issue (1), issn 2311-3162, 2014: 22-39.

Subramanyam, K.R., and John J Wild. Analisis Laporan Keuangan. Jakarta: Salemba Empat, 2010.

Wang, Junjie, Gang Fu, and Chao Luo. "Accounting Information and Stock Price Reaction of Listed Companies - Empirical Evidence from 60 Listed Companies in Shanghai Stock Exchange." Journal of Business and Management, vol (2), issue (2), issn 2291-1995, e-issn 2291-2002, 2013: 11-21. 